\title{
Hyperinsulinism due to INSR deficiency
}

INSERM

\section{Source}

INSERM. (1999). Orphanet: an online rare disease and orphan drug data base.

Hyperinsulinism due to INSR deficiency. ORPHA:263458

Hyperinsulinemic hypoglycemia due to INSR deficiency is a very rare autosomal dominant form of familial hyperinsulinism characterized clinically in the single reported family by postprandial hypoglycemia, fasting hyperinsulinemia, and an elevated serum insulin-to-C peptide ratio, and a variable age of onset. 